\title{
Eksploitasi Awak Kapal Asing: Tanggung Jawab Negara Bendera terhadap ABK Indonesia di Kapal China Long Xing 629
}

\author{
Yudi Dharmawan; Bernard Sipahutar; Mochammad Farisi \\ Fakultas Hukum Universitas Jambi \\ *Coresponding author: dharmawanyudi@gmail.com
}

$\begin{array}{ll}\text { Submission } & : 04 \text { Oktober } 2021 \\ \text { Revision } & : 31 \text { Januari } 2022 \\ \text { Publication } & : \text { 18 Februari } 2022\end{array}$

\begin{abstract}
This article discusses the form of legal protection and the flag state's responsibility for Indonesian crew members who work on foreign ships against exploitation in terms of international law. This article uses a normative juridical method, which is a method carried out by researching library materials or secondary data. The results of this articel discovered, that state flag responsibility for the legal protections for ship crews has to be done in a few ways such as conducting an investigation of the Long Xing 629 or the ship's company. If it proven that there had been a violation of human rights, the state flag have to prosecute the perpetrators of the crime that had committed on that ship. This responsibility have to done, cause the legal statue's of protection for the ships crew who worked on foreign vessels has been regulated under general nor specific international law instruments, as well others forms of legal protection are also given by international organizations such as ILO that specifically handles unternational labor issues.
\end{abstract}

Keyword: flag ship; legal protection; ship's crew 


\begin{abstract}
Abstrak
Artikel ini membahas tentang bagaimana bentuk perlindungan hukum dan tanggung jawab negara bendera terhadap awak kapal asal Indonesia yang bekerja di kapal asing terhadap eksploitasi ditinjau dari Hukum Internasional. Artikel ini menggunakan metode yuridis normatif, yaitu metode yang dilakukan dengan meneliti bahan pustaka atau data sekunder. Hasil pembahasan artikel ini menunjukan bahwa negara bendera wajib bertanggung jawab dengan melakukan penyelidikan terhadap kapal Long Xing 629 dan/atau perusahaan kapal tersebut. Jika terbukti terjadi pelanggaran HAM berupa eksploitasi terhadap awak kapal asal Indonesia, maka negara bendera harus mengadili para pelaku kejahatan yang dilakukan di atas kapal tersebut. Tanggung jawab tersebut harus dilaksanakan karena perlindungan hukum bagi awak kapal asal yang bekerja di kapal asing tercantum dalam instrumen-instrumen hukum internasional yang bersifat umum maupun khusus. Bentuk perlindungan hukum yang diberikan kepada awak kapal juga disalurkan melalui organisasiorganisasi internasional seperti ILO yang khusus menangani isu-isu buruh internasional.
\end{abstract}

Kata Kunci: awak kapal; bendera kapal; perlindungan hukum

\title{
A. Pendahuluan
}

Artikel ini membahas tentang dugaan eksploitasi pekerja awak kapal yang terjadi di atas kapal China Long Xing 629, dengan fokus topik tentang bagaimana bentuk perlindungan hukum serta tanggung jawab negara kapal terhadap korban dugaan eksploitasi menurut hukum internasional. Pada bagian pendahuluan, artikel ini akan membicarakan mengenai awak kapal dari sudut pandang hukum, baik dari instrumen hukum internasional maupun nasional serta kasus yang menjadi objek studi ini. Pada pembahasan pertama akan diulas mengenai bentuk perlindungan bagi awak kapal, dan pada pembahasan 
kedua, artikel ini akan mengulas mengenai tanggung jawab negara kapal.

Indonesia adalah negara penyumbang pekerja maritim terbesar ketiga di dunia, setelah China dan Filipina dengan jumlah awak kapal 1,2 juta orang yang saat ini bekerja pada kapal berbendara asing. Menurut UU No.18 Tahun 2017 Tentang Perlindungan Pekerja Migran, awak kapal juga merupakan pekerja migran. Bahkan perlindungan hukum bagi awak kapal dapat ditemukan dalam aturan hukum internasional yang secara umum dan secara khusus membahas tentang awak kapal.

Awak kapal yang akan ditempatkan memiliki perjanjian kerja yang dibuat sesuai dengan peraturan Indonesia dan peraturan nasional negara tempat awak kapal akan ditempatkan. Awal kapal wajib memiliki dokumen-dokumen seperti; perjanjian penempatan, perjanjian kerja laut, kartu tenaga kerja luar negeri, dan lain sebagainya. ${ }^{1}$ Sejak tahun 2005 sampai 2015 banyak awak kapal asal Indonesia yang bekerja di kapal penangkap ikan asing yang mengalami tindakan-tindakan tidak manusiawi seperti perkelahian, perdagangan manusia, diskriminasi, tindakan kekerasan, tidak terpenuhinya hak-hak

1 Riza Amalia, Ade Irma Fitriani, dan Bayu Sujadmiko. Perlindungan Hak Anak Buah Kapal Dalam Kerangka Hukum Nasional dan Hukum Internasional. Jurnal Ilmu Hukum. hal. 3. 
awak kapal tersebut, bahkan kerap untuk di eksploitasi.2 Pada tahun 2019 terjadi sebuah dugaan eskploitasi awak kapal Indonesia di kapal penangkap ikan Long Xing 629 milik perusahaan China. Awak kapal asal Indonesia bekerja selama 18 jam dalam waktu 24 jam, bahkan mereka diberikan makanan dan minuman yang sudah tidak layak konsumsi, upah yang diterima tidak sesuai, serta mereka mendapatkan perlakuan diskriminasi antara awak kapal asal Indonesia dengan asal China. $^{3}$

Tindakan-tindakan tersebut jelas melanggar pemenuhan hak awak kapal dalam Hukum Internasional dan Hukum Nasional di Indonesia. Pada kasus tersebut awak kapal asal Indonesia tidak mendapat jam istirahat ataupun perlakuan yang sesuai dengan hak-haknya. Padahal dalam konvensi ILO No.188 tahun 2007 telah jelas mengatur bahwa negara anggota harus memberikan hak bagi awak kapal yang sudah menjadi haknya. Dalam konvensi tersebut juga menjelaskan hak-hak para awak kapal untuk dapat diberi waktu istirahat yang cukup suapaya dapat menjaga kesehatan mereka

2 Gusrika Safitri. Perlindungan Anak Buah Kapal Indonesia Pada Kapal Perikanan Taiwan. JOM Fakultas Hukum, Vol. VI, Edisi 1. 2019. hal. 11.

${ }^{3}$ Chann Piseth. The Role of The 1982 United Nations On The Law of The Sea (UNCLOS) and The International Maritime Organization (IMO) For The Safety And Security of Ship's Crew During Sailing In International Shipping. Jurnal Poros Hukum Padjadjaran, Vol. 2, No. 1, 2020. hal. 161.

Uti Possidetis: Journal of International Law, Vol. 3, No. 1 (2022) 
Bahkan pada perjanjian kerja yang dibuat berdasarkan pada hukum nasional Indonesia juga telah memuat hak dan perlindungan hukum yang didapatkan pada saat mereka sedang bekerja sebagai migran kapal. Selain itu, awak kapal asal Indonesia juga dilindungi dalam Konvensi Internasional Mengenai Perlindungan Hak Semua Buruh Migran dan Anggota Keluarganya Tahun 1990. Terutama pada Pasal 10 yang secara tegas mengatur bahwa pekerja migran dan anggota keluarganya tidak boleh dijadikan sasaran penyiksaan atau perlakuan atau penghukuman yang kejam, tidak manusiawi dan merendahkan martabatnya.

Berdasarkan pada Konvensi Internasional tentang Perlindungan Hak Semua Buruh Migran dan Anggota Keluarganya Tahun 1990 dan Undang-Undang No. 18 Tahun 2017 tentang Perlindungan Pekerja Migran Indonesia, seharusnya awak kapal Indonesia sudah mendapatkan perlindungan Hukum. Akan tetapi banyak kasus awak kapal asal Indonesia yang bekerja di kapal penangkap ikan asing yang sangat kurang diperhatikan, bahkan ada banyak awak kapal yang tidak mendapatkan haknya, padahal perlindungan hukum terhadap awak kapal menjadi tanggung jawab negara tempat ia bekerja, dan negara pelabuhan. ${ }^{4}$

Walaupun Hukum Internasional telah menjamin hak-hak yang melekat pada manusia kepada siapapun bahkan

4 Riza Amalia, Ade Irma Fitriani, dan Bayu Sujadmiko, Loc Cit. 
dimanapun, tetapi pada praktiknya masih ada yang tidak mendapatkan haknya secara utuh dan menerima perlakuanperlakuan yang mengarah pada tindakan eksploitasi. Hal yang serupa juga terjadi pada kasus kapal kapal China Long Xing 629, dimana perlakuan-perlakuan yang mengarah pada eksploitasi telah terjadi, sehingga perlu dilihat dan diteliti bagaimana bentuk perlindungan hukum dan implementasinya secara menyeluruh.

\section{B. PEMBAHASAN}

\section{Bentuk Perlindungan Hukum Awak Kapal Asal Indonesia terhadap Eksploitasi ditinjau dari Hukum Internasional.}

perlindungan hukum Menurut Setiono adalah suatu tindakan atau upaya untuk melindungi masyarakat dari perbuatan yang sewenang-wenang yang dilakukan oleh penguasa yang tidak sesuai dengan aturan hukum, untuk mewujudkan ketertiban dan ketentraman sehingga memungkinkan manusia untuk menikmati harkat dan martabatnya sebagai manusia. ${ }^{5}$ Namun, menurut Philipus M. Hadjon, perlindungan hukum adalah perlindungan harkat dan

5 Karolina Rosalina Natkime. Peran Pemerintah Indonesia Dalam Memberikan Perlindungan Hukum Terhadap Anak Buah Kapal (ABK) Indonesia di Luar Negeri di Atas Kapal-Kapal Asing Berdasarkan Hukum Internasional. Skripsi Hukum Internasional, Universitas Atmajaya, Yogyakarta. 2018. hal. 45.

Uti Possidetis: Journal of International Law, Vol. 3, No. 1 (2022) 
martabat, serta pengakuan yang dilakukan terhadap hak asasi manusia yang dimiliki oleh subjek hukum. Maka dapat disimpulkan bahwa perlindungan hukum merupakan upaya untuk melindungi dari berbagai tindakan yang merugikan agar harkat dan martabat sebagai manusia tetap terjaga. Perlindungan hukum berlaku kepada setiap orang tanpa terkecuali agar setiap orang tersebut dapat menikmati hakhaknya. Dalam Declaration Universal of Human Rights 1948 menegaskan bahwa perlindungan hukum setiap orang sama didepan hukum tanpa diskriminasi apapun.

Dugaan kasus eksploitasi awak kapal asal Indonesia yang terjadi Pada Februari 2019. Sebanyak 22 awak kapal asal Indonesia diberangkatkan ke Busan, Korea Selatan, dan mulai berlayar dengan kapal Long Xing 629. Kasus ini menjadi hangat setelah sebuah video pelarungan mayat awak kapal asal Indonesia beredar di internet dan disiarkan oleh stasiun TV Korea Selatan yaitu MBC. berita tersebut menayangkan video yang menggambarkan perlakuan yang tidak manusiawi yang dilakukan kepada awak kapal asal Indonesia di kapal Long Xing 629. Terlihat jenazah yang dibungkus kain berwarna orange dilarung ke laut, pewarta MBC News menyebutkan video itu diperoleh dari awak kapal asal Indonesia ketika kapal penangkap ikan tersebut berlabuh di Busan, Korea Selatan pada tanggal 14 April, dan sejumlah awak kapal meminta pertolongan ke otoritas Busan namun ketika otoritas bergerak kapal tersebut sudah pergi. 
Perlakuan seperti memberi makan yang sudah kadaluarsa dan tidak layak konsumsi, serta meminum air laut yang disuling diterima oleh para awak kapal Indonesia. Perlakuan tidak manusiawi seperti bekerja melebihi jam kerja (18 jam perhari), dan perlakuan kasar seperti dipukul serta upah yang tidak layak dilakukan oleh pemilik kapal kepada para awak kapal Indonesia. Tindakan-tindakan tersebut di atas sangat jelas melanggar beberapa ketentuan yang secara rinci diatur di dalam pasal 14 ayat (1) huruf (b), pasal 27 huruf (a), (b), dan (c), dan pasal 23 Konvensi ILO No.188 Tahun 2007 mengenai Pekerjaan Dalam Penangkapan Ikan.

Eksploitasi yang di alami oleh awak kapal asal Indonesia sangat berkaitan dengan hak asasi manusia (HAM) karena hak asasi manusia merupakan hak yang telah dimiliki oleh setiap orang sejak ia dalam kandungan (dalam keadaan hidup) sampai ia meninggal dan tidak dapat diganggu oleh siapapun, sehingga negara memiliki kewajiban untuk memberikan perlindungan kepada awak kapal yang bekerja di luar negeri. Maka dari itu negara berkewajiban untuk memberikan perlindungan mengenai Hak Asasi warga negara yang menjadi awak kapal di kapal Long Xing 629 dengan asas kesetaraan, hak untuk hidup, keadilan sosial, demokrasi, non-diskriminasi dan pelanggaran HAM. ${ }^{6}$

${ }^{6}$ Ibid.

Uti Possidetis: Journal of International Law, Vol. 3, No. 1 (2022) 
Perlindungan awak kapal sangat perlu diperhatikan karena sampai saat ini banyak sekali awak kapal asal Indonesia yang bekerja di kapal asing diperlakukan tidak manusiawi dan rentan untuk dieksploitasi, serta menjadi korban pelanggaran hak asasi manusia (HAM), dan banyak sekali awak kapal yang mengalami kesulitan dikarenakan upah yang mereka terima tidak layak, bahkan sering kali mengalami diskriminasi diatas kapal antara awak kapal asal Indonesia dengan awak kapal asal China. ${ }^{7}$ Padahal aturan tentang perlindungan awak kapal telah ditetapkan dalam instrumen hukum internasional yang bersifat umum maupun khusus.

Berdasarkan pada Pasal 1, Pasal 4, Pasal 5 dan Pasal 7 Declaration Universal of Human Rights, perlindungan awak kapal dari eksploitasi tidak selalu terkait dengan profesi awak kapal itu sendiri, tetapi memperhatikan dan memperlakukan serta melindungi pribadinya sebagai manusia yang harus dijaga harkat dan martabatnya. Semua orang berhak untuk mendapatkan perlindungan yang sama terhadap diskriminasi apapun.

Perlindungan hukum bagi pekerja migran, terutama awak kapal diatur dalam Pasal 9, Pasal 10, Pasal 11 Ayat (1) International Convention On The Protection Of The Rights of All

${ }^{7}$ Riza Amelia, Ade Irma Fitriani, Bayu Sujadmiko, Op Cit, hal. 2. 
Migrant Workers And Members Of Their Families ${ }^{8}$. Dalam Pasal tersebut semua buruh migran memiliki hak untuk hidup termasuk keluarganya, tidak boleh dijadikan objek penyiksaan, maupun perlakuan yang tidak manusiawi, dan tidak boleh untuk diperbudak.

Secara khusus perlindungan awak kapal juga diatur di dalam Konvensi ILO No. 188 Tahun 2007 tentang Pekerjaan Dalam Penangkapan Ikan (Work in Fishing Convention, 2007) Pasal 8 Ayat (2):

"Nakhoda bertanggung jawab atas keselamatan awak kapal yang ada di kapal serta pengoperasian kapal secara aman, namun tidak termasuk terbatas pada bidang-bidang berikut ini:

(a) Menyediakan pengawasan untuk memastikan bahwa, sejauh mungkin, awak kapal melaksanakan tugas mereka dalam kondisi keselamatan dan kesehatan terbaik;

(b) Mengelola awak kapal dengan cara yang menghormati keselamatan dan kesehatan, termasuk mencegah rasa letih;

(c) Memfasilitasi pelatihan pengetahuan tentang kesehatan dan keselamatan kerja di kapal; dan

(d) Memastikan kepatuhan terhadap keselamatan navigasi, penjagaan dan standar pelayanan yang baik."

Bentuk perlindungan hukum yang diberikan kepada awak kapal juga disalurkan melalui organisasi-organisasi internasional seperti ILO (International Labour Organization)

8 Disebut juga dengan Konvensi Internasional Tentang Perlindungan Hak Semua Buruh Migran dan Anggota Keluarganya Tahun 1999.

Uti Possidetis: Journal of International Law, Vol. 3, No. 1 (2022) 
yang khusus menangani isu-isu buruh internasional dan melalui lembaga atau badan-badan nasional di Indonesia seperti Kementerian Ketenagakerjaan, Kementerian Kelautan dan Perikanan, Badan Perlindungan Pekerja Migran Indonesia (BP2MI), dan lain sebagainya. Saat ini Konvensi ILO No.188 Tahun 2007 mengenai Pekerjaan Dalam Penangkapan Ikan belum diratifikasi namun Indonesia mengeluarkan pernyataan bahwa Indonesia akan melakukan persiapan ratifikasi dengan optimalisasi pelaksanaan peraturan nasional yang mengadopsi ketentuan dalam konvensi tersebut. ${ }^{9}$

Walaupun Indonesia belum meratifikasi Konvensi ILO No.188 Tahun 2007 tetapi Indonesia mempunyai hak untuk mengimplementasi muatan konvensi tersebut, dan negara berhak untuk melakukan penegakan hukum apabila terjadi perlakuan yang tidak manusiawi terhadap awak kapal asal Indonesia yang bekerja di kapal penangkap ikan asing. Selain aturan-aturan hukum internasional yang bersifat umum beserta instrumen-instrumennya yang bersifat khusus, perlindungan awak kapal juga diatur dalam hukum nasional, walaupun belum ada aturan khusus mengenai awak kapal di bidang perikanan, akan tetapi awak kapal asal Indonesia yang bekerja di kapal penangkap ikan asing termasuk buruh migran dan perlindungan buruh migran dilindungi oleh hukum

9 Ratifikasi ILO No.188 Indonesia, https://maritim.go.id/ kemenko-marves-tekankan-komitmen-percepat-ratifikasi-konvensiilo/ diakses pada 22 September 2021, pukul 15.53 WIB.

Uti Possidetis: Journal of International Law, Vol. 3, No. 1 (2022) 
nasional, seperti halnya dalam Undang-Undang Nomor 18 Tahun 2017 tentang Perlindungan Pekerja Migran Indonesia, dalam ketentuan Pasal 1 angka 5 menetapkan bahwa: ${ }^{10}$

"Perlindungan Pekerja Migran Indonesia adalah segala upaya untuk melindungi kepentingan calon pekerja migran Indonesia dan/atau pekerja migran Indonesia dan keluarganya dalam mewujudkan terjaminnya pemenuhan haknya dalam keseluruhan kegiatan sebelum bekerja, selama bekerja, dan setelah bekerja dalam aspek hukum, ekonomi, dan sosial".

Perlindungan awak kapal juga diatur di dalam Peraturan Menteri Kelautan dan Perikanan Nomor-42/PERMEN-KP/2016 tentang Perjanjian Kerja Laut Bagi Awak Kapal Perikanan. pada pokoknya aturan tersebut mengatur bahwa pemilik ataupun nakhoda kapal perikanan harus memastikan tersedianya kebutuhan pokok, baik makanan, kesehatan, kondisi mental serta kebugaran jasmani para awak kapal selama beroperasi. Bahkan jaminan keselamatan bagi awak kapal, dan juga jam kerja di atas kapal, serta jaminan perlindungan hukum diatur dalam peraturan ini, agar kesehatan, keselamatan dan kesejahteraan awak kapal terjamin. ${ }^{11}$

10 Karolina Rosalina Natkime, Op Cit, hal. 55.

11 Umi Kurniawati. Tinjauan Yuridis Eksploitasi ABK Indonesia Dalam Tindak Pidana Perdagangan Orang. Dinamika, Volume 27, Nomor 1. 2021, hal. 13.

Uti Possidetis: Journal of International Law, Vol. 3, No. 1 (2022) 
Berdasarkan sifatnya, Bentuk perlindungan hukum terhadap awak kapal asal Indonesia yang bekerja di kapal penangkap ikan asing berupa:12

a. Bentuk perlindungan hukum preventif, perlindungan hukum yang diberikan oleh pemerintah yaitu memberikan kesempatan kepada awak kapal asal Indonesia yang bekerja di kapal penangkap ikan asing untuk mengajukan keberatan (inspraak) atas pendapatnyasebelum suatu keputusan pemerintahan yang sudah pasti. Guna agar pemerintah dalam mengambil keputusan didasarkan pada kebijakan.

b. Bentuk perlindungan hukum represif, perlindungan hukum represif merupakan perlindungan akhir yang berupa sanksi misalnya denda, penjara dan hukuman tambahan yang diberikan apabila telah dilakukan suatu pelanggaran.

Dalam menecegah kasus pelanggaran terhadap awak kapal, Indonesia telah berupaya untuk meningkatkan kualitas perlindungan awak kapal dalam penempatan awak kapal, keamanan, dan kenyamanan pekerja. ${ }^{13}$ Perlindungan tersebut dapat dilihat dari bagaimana Indonesia meratifikasi instrumen internasional dan membentuk instrumen hukum nasional

\section{Ibid.}

13 Fera Septi Anjani. Implementasi Hukum Terhadap Eksploitasi ABK Indonesia Di Kapal China Berdasarkan Maritime Labour Convention 2006. Fakultas Ilmu Hukum, Universitas Muhammadiyah Yogyakarta, Januari, 2022, hal. 10. 
lainnya. Di sisi lain, terdapat lembaga-lembaga negara yang berwenang untuk memberikan perlindungan terhadap para awak kapal yang bersifat preventif dan represif.

\section{Tanggung Jawab Negara Bendera Kapal Terkait Perlindungan Hukum Bagi Awak Kapal Asal Indonesia.}

Konsep tanggung jawab (responsibility) mempunyai makna bahwa tanggung jawab tidak hanya berupa kewajiban (obligation) untuk memenuhi apa yang pernah dilakukan terkait keputusan, keahlian, serta kemampuan seseorang, tetapi juga kemampuan untuk memulihkan (restitution) terhadap kerugian yang dilakukan. Dengan kata lain bahwa responsibility tidak hanya meliputi tanggung jawab hukum, tetapi termasuk juga tanggung jawab moral, dengan demikian tanggung jawab tidak dapat dilepaskan dari makna kewajiban, maka dari pada itu tanggung jawab sering diartikan sama penggunaannya dengan istilah kewajiban. ${ }^{14}$

Dalam ketentuan Pasal 38 Ayat (1) Statuta Mahkamah Internasional tanggung jawab negara juga merupakan asas dasar di dalam hukum internasional dan berasal dari doktrin para ahli hukum internasional, yaitu apakah kewajiban tersebut berdasarkan perjanjian internasional atau kebiasaan

14 Ida Hanifah. Peran dan Tanggung Jawab Negara Dalam Perlindungan Hukum Tenaga Kerja Indonesia Yang Bermasalah di Luar Negeri. Jurnal Ilmu Hukum, Volume 5 Nomor 1. 2020. hal. 18. 
internasional, maka tanggung jawab negara akan muncul. Dengan demikian pertanggungjawaban berarti kewajiban yang memberikan jawaban terhadap suatu hal yang telah terjadi, serta memberikan kerugian yang telah ditimbulkan.

Hukum internasional belum memberikan definisi yang konkret mengenai tanggung jawab negara. Namun, pada pasal 1 draft articles on Responsibility of States for Internationally Wrongful Acr 2001 oleh International Law Commission menegaskan bahwa "Responsibility of a State for its internationally wrongful acts. Every internationally wrongful act of a state entails the international responsibility of the state", dalam hal ini dimana negara yang melanggar aturan hukum internasional menimbulkan tanggung jawab negara. ${ }^{15}$

Dengan kata lain tanggung jawab negara merupakan aturan internasional yang mnegatur tentang akibat hukum yang timbul karena terjadinya pelanggaran kewajibankewajiban internasional negara-negara, kewajiban tersebut bersumber dari konvensi internasional, traktat, ataupun kebiasaan internasional. ${ }^{16}$

${ }^{15}$ Emilio Timnie K R. Tinjauan Hukum Internasional Tentang Pelarungan Anak Buah Kapal (Studi Kasus Pelarungan Anak Buah Kapal Indonesia Dari Kapal Cina), Skripsi Fakultas Hukum, Universitas Sumatera Utara, Medan, hal. 72.

${ }^{16}$ Ibid, hal. 73 
Tanggung jawab negara timbul sebagai akibat dari pelanggaran hukum internasional yang dilakukan oleh suatu negara, yaitu: ${ }^{17}$

1. Tindakan yang dilakukan melanggar hak asasi manusia, atau melakukan pembiaran (ommission) terhadap suatu pelanggaran hak asasi manusia;

2. Tindakan yang dilakukan merupakan pelanggaran terhadap suatu kewajiban internasional.

Selain tindakan diatas, lahirnya tanggung jawab negara dipengaruhi oleh 2 teori. Pertama teori resiko (risk theory) teori ini menghasilkan prinsip teori tanggung jawab mutlak (absolute liability) atau tanggung jawab objektif (objective responsibility) yaitu negara mutlak bertanggung jawab terhadap seluruh kegiatan yang menimbulkan akibat yang membahayakan walaupun tindakan yang dilakukan adalah tindakan yang sah menurut hukum. Kedua, teori kesalahan (fault theory) teori ini menghasilkan prinsip tanggung jawab subjektif (subjective responsibility) yaitu bahwa tanggung jawab negara atas perbuatannya baru dikatakan ada jika dapat dibuktikannya adanya unsur kesalahan pada perbuatan itu. ${ }^{18}$

Berdasarkan pasal 17 International Convent on Political Right, bahwa setiap orang berhak atas perlindungan hukum

17 Yanes S. Merentek. Tanggung Jawab Negara Dalam Perlindungan Hak Asasi Manusia Menurut Hukum Internasional. Lex Privatum, Vol. 6, No. 9. 2018. hal. 182.

${ }^{18}$ Emilio Timnie K R, Op Cit, hal. 73.

Uti Possidetis: Journal of International Law, Vol. 3, No. 1 (2022) 
dari berbagai bentuk campur tangan atau gangguan. Maka dari itu, Setiap negara bertanggung jawab atas warga negaranya baik yang tinggal di dalam wilayahnya ataupun yang berada diluar wilayahnya serta warga negara asing yang berada dalam wilayahnya.

Dalam kasus pada kapal penangkap ikan asing (Long Xing 629), perlakuan yang diterima oleh awak kapal Indonesia termasuk dalam pelanggaran hak asasi manusia. Berdasarkan teori hak kodrati dari John Locke setiap orang, karena hukum kodrat berhak atas kehidupan, kebebasan dan harta milik agar dapat bertahan hidup. ${ }^{19}$ Maka dari itu, eksploitasi yang dilakukan oleh kapal Long Xing 629 tidak boleh dilakukan karena telah melanggar hak asasi manusia. Oleh karena itu, sudah seharusnya negara bendera bertanggung jawab kepada awak kapal yang mengalami masalah di atas kapal, baik itu dari pelanggaran hak asasi manusia, perbudakan, bahkan eksploitasi awak kapal.

Negara bendera kapal dapat melakukan pertanggungjawabannya dengan cara berupa, pertama Satisfaction yaitu pemulihan atas suatu perbuatan yang melanggar kehormatan negara, dilakukan dengan cara perundingan pejabat diplomatik serta cukup dengan mewujudkan permohonan maaf secara resmi dengan jaminan

19 Muhammad Asri, Hak Asasi Manusia Filosofi, Teori \& Instrumen Dasar, Cetakan Pertama, CV. Social Polittic Genius (SIGn), Makassar, 2018, hal. 27-28. 
tidak terulang lagi perbuatan itu. Kedua, Premiery reparation, yaitu negara dapat melakukan tanggung jawabnya jika pelanggaran tersebut menimbulkan kerugian material.

Dalam hukum internasional, ciri-ciri penting dalam pertanggungjawaban negara memiliki beberapa faktor: pertama, adanya kewajiban hukum internasional yang masih berlaku di antara kedua negara yang bersangkutan; kedua, telah terjadi suatu perbuatan atau kelalaian yang melanggar kewajiban; ketiga, kelalaian ataupun perbuatan tersebut menimbulkan kehilangan atau kerugian. ${ }^{20}$ Tanggung jawab negara juga ditentukan oleh norma-norma internasional (walaupun dalam cabang-cabang khusus mungkin memasukkan norma-norma nasional) dan tergantung sejauh mana tindakan atau kelalaian yang melanggar hukum. ${ }^{21}$

Adapun negara yang bertanggung jawab terhadap awak kapal asal Indonesia yang bekerja di kapal penangkap ikan asing adalah negara asal, negara pelabuhan, dan negara bendera. Tanggung jawab negara asal dan negara bendera terdapat dalam suatu perjanjian kerja yang dibuat sebelum awak kapal bekerja pada kapal penangkap ikan antara awak kapal dan pemilik kapal yang disebut perjanjian kerja awak kapal, perjanjian ini dibuat berdasarkan peraturan perundang-

20 Malcolm N. Shaw QC, Hukum Internasional, Edisi Keenam, Cet-1, Nusa Media, Bandung, 2013, hal. 774.

21 J.G Starke, Pengantar Hukum Internasional, Edisi Ke-9, Aksara Persada Indonesia, Jakarta, 1988, hal. 275. 
undangan yang berlaku di negara asal dan negara bendera. ${ }^{22}$ Dan tanggung jawab negara pelabuhan adalah ketika kapal penangkap ikan memasuki wilayah territorial dari negara pelabuhan, sehingga yurisdiksi yang berlaku terhadap kapal dan awak kapal adalah yurisdiksi dari negara pelabuhan tersebut. $^{23}$

Keselamatan dan keamanan bagi awak kapal terdapat dalam Konvensi Hukum Laut PBB Tahun 1982 (United Nations Convention Law of The Sea 1982), walaupun konvensi ini tidak mengatur secara khusus tentang awak kapal, namun perlindungan terkait awak kapal dapat dikaitkan dengan tanggung jawab dari negara bendera. ${ }^{24}$ Maka dari itu, tanggung jawab negara terhadap permasalahan yang ditimbulkan dalam kasus awak kapal asal Indonesia yang bekerja di kapal penangkap ikan China Long Xing 629, karena sudah seharusnya negara China bertanggung jawab.

Dalam kasus ini Indonesia selaku negara pengirim awak kapal dapat mendesak negara bendera untuk memenuhi hak para awak kapal yang belum terpenuhi serta memberikan pemulihan hak lainnya dari segi kesehatan, mental, upah dan lain sebagainya, dan wajib bertanggung jawab dengan melakukan penyelidikan terhadap kapal Long Xing 629 dan/atau perusahaan kapal tersebut, dan jika terbukti terjadi

\footnotetext{
22 Gusrika Safitri, Loc Cit.

23 Ibid.

${ }^{24}$ Chann Piseth, Op Cit, hal. 168.
} 
pelanggaran HAM dalam hal ini adalah eksploitasi terhadap awak kapal asal Indonesia maka negara bendera harus mengadili para pelaku kejahatan yang dilakukan di atas kapal tersebut. 25

\section{Penutup}

Berdasarkan dari pembahasan di atas maka dapat ditarik kesimpulan yaitu, Perlindungan hukum bagi awak kapal asal Indonesia yang bekerja di kapal asing terhadap eksploitasi telah diatur dalam instrumen-instrumen hukum internasional yang bersifat umum seperti Declaration Universal of Human Rights Tahun 1948 tentang hak dasarnya sebagai manusia, Konvensi Internasional Mengenai Perlindungan Semua Hak Buruh Migran dan Anggota Keluarganya Tahun 1990, dan khusus seperti Konvensi ILO No. 188 tentang Pekerjaan Dalam Penangkapan Ikan Tahun 2007, serta dalam hukum nasional seperti, Undang-Undang Nomor 18 Tahun 2017 tentang Perlindungan Pekerja Migran Indonesia.

Negara bendera bertanggung jawab sesuai pada ketentuan United Nations Convention on the Law of the Sea 1982 Pasal 94 sesuai dengan kewajibannya yaitu memberikan perlindungan hukum bagi awak kapal asal Indonesia dengan cara melakukan penyelidikan terhadap kapal Long Xing 629

${ }^{25}$ Ahriani, Josina Augustina Yvonne Wattimena, dan Arman Anwar, Tanggung Jawab Negara Bendera Kapal Terhadap Perbudakan ABK Indonesia, Jurnal Ilmu Hukum, Volume 1 Nomor 2, 2021, hal. 57. 
dan/atau perusahaan kapal tersebut. Jika terbukti melakukan pelanggaran HAM dalam hal ini adalah eksploitasi awak kapal asal Indonesia maka negara bendera harus mengadili para pelaku kejahatan serta wajib memenuhi hak-hak awak kapal asal Indonesia yang belum terpenuhi.

\section{Referensi}

Ahriani, Josina Augustina Yvonne Wattimena, dan Arman Anwar, Tanggung Jawab Negara Bendera Kapal Terhadap Perbudakan ABK Indonesia, Jurnal Ilmu Hukum, Volume 1 Nomor 2, 2021.

Amalia, R. Ade Irma Fitriani, dan Bayu Sujadmiko, "Perlindungan Hak Anak Buah Kapal Dalam Kerangka Hukum Nasional Dan Hukum Internasional”, Jurnal Ilmu Hukum, Universitas Lampung.

Anjani, F.S. Implementasi Hukum Terhadap Eksploitasi ABK Indonesia Di Kapal China Berdasarkan Maritime Labour Convention 2006, Fakultas Ilmu Hukum, Universitas Muhammadiyah Yogyakarta, Januari, 2022.

Asri, M. Hak Asasi Manusia Filosofi, Teori \& Instrumen Dasar, Cetakan Pertama, CV. Social Polittic Genius (SIGn), Makassar, 2018.

Hanifah, I. Peran dan Tanggung Jawab Negara Dalam Perlindungan Hukum Tenaga Kerja Indonesia Yang Bermasalah di Luar Negeri, Jurnal Ilmu Hukum, Volume 5 Nomor 1, 2020.

Kurniawati, U. Tinjauan Yuridis Eksploitasi ABK Indonesia Dalam Tindak Pidana Perdagangan Orang, Dinamika, Volume 27, Nomor 1, 2021. 
Merentek, Y.S. Tanggung Jawab Negara Dalam Perlindungan Hak Asasi Manusia Menurut Hukum Internasional, Lex Privatum, Vol. VI, No. 9, 2018.

Natkime, K.R. Peran Pemerintah Indonesia Dalam Memberikan Perlindungan Hukum Terhadap Anak Buah Kapal (ABK) Indonesia di Luar Negeri di Atas Kapal-Kapal Asing Berdasarkan Hukum Internasional, Skripsi Hukum Internasional, Universitas Atmajaya, Yogyakarta, 2018.

Piseth, C. The Role of The 1982 United Nations On The Law of The Sea (UNCLOS) and The International Maritime Organization (IMO) For The Safety And Security of Ship's Crew During Sailing In International Shipping, Jurnal Poros Hukum Padjadjaran, Vol. 2, Nomor. 1, 2020.

Ratifikasi ILO No.188 Indonesia, https://maritim.go.id/kemenkomarves-tekankan-komitmen-percepat-ratifikasi-konvensi -ilo/ diakses pada 22 September 2021, pukul 15.53 WIB.

Safitri, G. Perlindungan Anak Buah Kapal Indonesia Pada Kapal Perikanan Taiwan, JOM Fakultas Hukum, Vol. VI, Edisi 1, 2019.

Shaw, Malcolm N QC. Hukum Internasional, Edisi Keenam, Cet-1, Nusa Media, Bandung, 2013.

Starke, J.G. Pengantar Hukum Internasional, Edisi Ke-9, Aksara Persada Indonesia, Jakarta, 1988.

Timnie, E.K.R. Tinjauan Hukum Internasional Tentang Pelarungan Anak Buah Kapal (Studi Kasus Pelarungan Anak Buah 
Eksploitasi Awak Kapal Asing...

Kapal Indonesia Dari Kapal Cina), Skripsi Fakultas Hukum, Universitas Sumatera Utara, Medan, 2021.

Uti Possidetis: Journal of International Law, Vol. 3, No. 1 (2022) 